\title{
PENGARUH INTEGRATED MARKETING COMMUNICATION TERHADAP BRAND EQUITY PERBANKAN SYARIAH DI KOTA MALANG
}

\author{
Yayuk Sri Rahayu \\ Fakultas Ekonomi UIN Maulana Malik Ibrahim Malang \\ Jl Gajayana 50 Malang \\ yayukfeuinmalang@gmail.com
}

Abtract

This research aimed to know the influence of integrated marketing communication to brand equity of sharia banking at Malang simoultaneusly and partially. Used 102 respondents with accidental sampling method and data was analized by multiple linier regression. The result shows, first, integrated marketing communication influenced simoultaneusly to brand equity of sharia banking at Malang. Second, only one variable that influenced partially to brand equity of sharia banking at Malang, the variable is public relation. So there is not dominant variable.

Keywords: Integrated marketing communication, brand equity

Dewasa ini persaingan di sektor perbankan semakin ketat yang ditandai dengan semakin intensifnya peluncuran produk-produk unggulan dalam rangka peningkatan mutu pelayanan kepada nasabah. Bank Syariah sebagai salah satu pelaku bisnis perbankan mengalami pertumbuhan yang cukup pesat dan juga bersaing dengan bank lain baik perbankan syariah sendiri maupun konvensional. Pertumbuhan aset perbankan syariah di Malang, Jawa Timur pada semester pertama 2010 menggembirakan dan merupakan pertumbuhan terbaik dalam tiga tahun terakhir (Tempo, 2010). Pemimpin Bank Indonesia Malang Totok Hermiyanto menambahkan, animo masyarakat Malang Raya (Kabupaten Malang, Kota Malang, dan Kota Batu) 
terhadap layanan perbankan syariah cukup tinggi. Sebagian masyarakat muslim bahkan fanatik memilih perbankan syariah yang tidak mengenal riba,tapi pembagian hasil. Di wilayah KBI Malang terdapat enam kantor cabang bank syariah, yakni PT Bank Syariah Mandiri, PT Bank Negara Indonesia Syariah, PT Bank Muamalat Indonesia, PT Bank Rakyat Indonesia Syariah, PT Bank Mega Syariah, dan PT Bank Tabungan Negara Syariah.

Untuk memenangkan persaingan tersebut maka bank harus menguatkan ekuitas mereknya (brand equity). Menurut Aaker dalam Susanto dan Wijanarko (2004:125), ekuitas merek (brand equity) adalah seperangkat aset dan liabilitas merek yang berkaitan dengan suatu merek, nama dan simbolnya, yang menambah atau mengurangi nilai yang diberikan oleh suatu produk atau jasa kepada pelanggan. Oleh karena itu, menciptakan brand equity dari suatu perusahaan merupakan masalah yang cukup penting, karena dapat mempengaruhi hidup matinya serta laba dari perusahaan (Kotler, 2006:349).

Untuk membangun dan mempertahankan brand equity dapat dilakukan melalui komunikasi pemasaran yang tepat (Mudhavaram, et al., 2005). Komunikasi pemasaran terpadu (Integrated Marketing Communiccation) adalah kegiatan yang berupaya memadukan antara periklanan dengan alat-alat komunikasi pemasaran lainnya seperti humas, pemasaran langsung, promosi penjualan serta event sponsorship untuk bisa bekerja bersama-sama (Kotler \& Armstrong, 2001:138). Komunikasi pemasaran terpadu ditujukan untuk memelihara brand awareness, brand loyalty, memantapkan citra karakter tiap brand, serta mengkomunikasikan desain-desain tiap brand dan program-program penjualan, di tengah-tengah persaingan di lingkungan bisnis. Komunikasi pemasaran juga berdampak terhadap perilaku konsumen (Mihart, 2012). Cara yang perlu ditempuh adalah dengan mengintegrasikan bauran komunikasi pemasaran yang mampu menjangkau konsumen dari segala arah. Dengan demikian, program komunikasi pemasaran yang dijalankan akan menghasilkan dampak yang maksimal terhadap peningkatan brand equity (Nasiha, 2010).

IMC mempunyai peran penting dalam mempengaruhi konsumen untuk melakukan pembelian dan memiliki nilai yang signifikan dalam pengembangan brand equity perusahaan (Brunello, 2013). Hasil penelitian Aulia Danibrata (2011) menyatakan bahwa IMC berpengaruh terhadap brand equity pada bank pemerintah. IMC juga merupakan dimensi pembentuk brand awareness (Widyakusuma, 2012). Fathir Fathoni, Achmad Fauzi dan Kadarisman Hidayat (2011) melakukan penelitian tentang Pengaruh Komunikasi Pemasaran Terpadu Terhadap Ekuitas Merek dan hasil penelitian menunjukkan bahwa variabel dari komunikasi pemasaran terpadu yaitu iklan, promosi penjualan, penjualan personal, hubungan masyarakat, pemasaran langsung, pemasaran interaktif dan corporate design secara bersama sama berpengaruh terhadap ekuitas merek, sedangkan secara parsial diketahui 
hanya variabel promosi penjualan, penjualan personal, pemasaran interaktif, dan corporate design yang berpengaruh signifikan terhadap ekuitas merek.

Oleh karena pentingnya peranan IMC dalam menguatkan brand equity maka perlu dilakukan penelitian mengenai pengaruh IMC terhadap brand equity perbankan syariah di Kota Malang. Penelitian ini bertujuan untuk mengetahui pengaruh intergrated marketing communication secara simultan dan parsial terhadap brand equity perbankan syariah di Kota Malang serta untuk mengetahui variabel intergrated marketing communication yang berpengaruh dominan terhadap brand equity perbankan syariah di Kota Malang.

\section{Integrated Marketing Communication}

Komunikasi pemasaran terpadu (Integrated Marketing Communiccation) adalah kegiatan yang berupaya memadukan antara periklanan dengan alat-alat komunikasi pemasaran lainnya seperti humas, pemasaran langsung, promosi penjualan serta event sponsorship untuk bisa bekerja bersama-sama (Kotler \& Armstrong, 2001, hal. 138).

Periklanan (advertising): Segala biaya yang harus dikeluarkan sponsor untuk melakukan presentasi dan promosi nonpersonal dalam bentuk gagasan, barang, atau jasa. Contoh: Iklan media cetak, iklan media elektronik, brosur, buklet, poster, leaflet, billboard, dan lain-lain.

Promosi penjualan (sales promotion): Berbagai insentif jangka pendek untuk mendorong pembelian atau penjualan suatu produk atau jasa. Contoh: Kupon, hadiah, diskon, produk sample, pameran dagang, games, dan lain-lain.

Hubungan masyarakat dan publisitas (public relations \& publicity): Membangun hubungan baik dengan publik terkait untuk memperoleh dukungan, membangun "citra perusahaan" yang baik, dan menangani atau mengklarifikasi isu, cerita, dan peristiwa yang dapat merugikan. Sedangkan publisitas adalah stimulasi nonpersonal terhadap permintaan barang, jasa, ide, dan sebagainya dengan berita komersial yang berarti dalam media massa, dan tidak berbayar untuk mempromosikan dan untuk melindungi citra perusahaan atau produknya. Contoh: Seminar, press release, sponsorship, majalah perusahaan, events, lobbying, dan lain-lain.

Penjualan personal (personal selling): Interaksi langsung dengan satu calon pembeli atau lebih untuk melakukan presentasi dalam rangka mensukseskan penjualan dan membangun hubungan dengan pelanggan. Contoh: Presentasi penjualan, pameran dagang, dan program insentif.

Pemasaran langsung (direct marketing): Komunikasi langsung dengan sejumlah konsumen sasaran untuk memperoleh tanggapan langsung. Contoh: Katalog, surat, telemarketing, fax mail, internet, dan lain-lain. 


\section{Brand Equity}

Menurut Kotler (2006:334) ekuitas merek (brand equity) adalah nilai konsumen yang diberikan pada produk atau jasa. Aaker dalam Tjiptono (2005:39) menyatakan bahwa ekuitas merek (brand equity) adalah serangkaian aset dan kewajiban (liabilities) merek yang terkait dengan sebuah merek, nama dan simbolnya, yang menambah atau mengurangi nilai yang diberikan sbuah produk atau jasa kepada perusahaan atau pelanggan perusahaan tersebut. Ekuitas merek terdiri atas lima komponen: loyalitas, kesadaran merek, mutu yang dirasakan, asosiasi merek, dan aset-aset merek lainya (Simamora, 2007:439).

Menurut Hermawan Kartajaya (2009:62) merek sebagai asset yang menciptakan value bagi pelanggan dengan meningkatkan kepuasan menghargai kualitas. Merek yang dimiliki oleh perusahaan akan menjadi kuat bila memiliki brand equity yang juga kuat. Brand equity yang kuat akan lebih mudah dalam mendongrak produk atau unit bisnis lain dari perusahaan, dimensi brand equity meliputi:

\section{Brand awareness}

Menurut Simamora (2007:439), merupakan suatu ukuran seberapa banyak pelanggan potensial mengetahui sebuah merek. Strategi yang lazim dalam pemasaran dan periklanan adalah mempertinggi tingkat kesadaran merek. Pada hakikatnya, orang tidak akan membeli produk yang tidak mereka ketahui, namun keakrabannya dengan produk juga merupakan pengaruh pembelian yang kuat.

Sedangkan menurut Shimp (2003:11) merupakan kemampuan sebuah merek untuk muncul dalam benak kosumen ketika mereka sedang memikirkan ketegori produk tertentu dan seberapa mudahnya nama tersebut dimunculkan (Tjiptono, 2005:40) Yaitu kemampuan konsumen untuk mengenali atau mengingat bahwa sebuah merek merupakan anggota dari ketegori produk tertentu.

Begitu juga dengan menurut Susanto dan Wijarnako (2004:130), kesadaran merek berada pada rentang antara perasaan yang tak pasti terhadap pengenalan suatu merek sampai dengan perasaan yakni bahwa produk tersebut merupakan satu-satunya dalam kelas produk yang bersangkutan.

\section{Brand association}

Menurut Simamora (2007:439), merupakan persepsi dan citra yang dikaitkan oleh orang-orang dengan merek tertentu. Patut dicatat bahwa asosiasi merek dapat pula negatif dan hal itu dapat atau memotong ekuitas sebuah merek. (Tjiptono, 2005:40) yakni segala sesuatu yang terkait dengan memori terhadap sebuah merek, lebih erat dengan brand image, yang didefinisikan sebagai serangkaian asosiasi merek dengan makna tertentu asosiasi merek memiliki tingkat kekuatan tertentu dan akan semakin kuat seiring dengan bertambahnya pengalaman konsumsi atau eksposur dengan merek spesifik. 


\section{Brand Loyalty}

Menurut Simamora (2007:439), mengacu kepada tingkat komitmen para pelanggan terhadap sebuah merek tertentu. Manfaat utama loyalitas merek adalah adanya jaminan terhadap kerugian pangsa pasar yang signifikan manakala competitor baru memasuki ajang pertarungan. David Aaker dalam buku managing brand equity. (Susanto dan Wijarnako, 2004:127), Sedangkan menurut Hermawan Kartajaya (2009:64), mendefinisikan bahwa brand loyality adalah sebuah ukuran ketertarikan pelanggan terhadap suatu merek.

\section{Perceived Quality}

Menurut Simamora (2007:439) sebagai persepsi pelanggan terhadap kualitas atau keunggulan suatu produk atau jasa sehubungan dengan tujuan yang diinginkan, dibandingkan alternatif-alternatif lain. (Tjiptono, 2005:40), merupakan penilaian konsumen terhadap keunggulan atau superioritas produk secara keseluruhan. Oleh sebab itu, perceived quality didasarkan pada evaluasi subyektif konsumen (bukan manajer atau pakar) terhadap produk.

\section{Kerangka Pikir}

Berdasarkan penelitian terdahulu dan landasan teori maka disusun kerangka pikir sebagai berikut:



\section{Hipotesis}

- Variabel integrated marketing communication berpengaruh secara simultan terhadap brand equity.

- Variabel integrated marketing communication berpengaruh secara parsial terhadap brand equity.

- Variabel advertising berpengaruh dominan terhadap brand equity. 


\section{METODE PENELITIAN}

\section{Lokasi Penelitian}

Penelitian ini dilakukan pada Perbankan syariah di Kota Malang karena adanya persaingan brand yang cukup ketat antara perbankan syariah dengan perbankan kovensional. Sehingga perbankan syariah perlu untuk melakukan kegiatan integrated marketing communication dalam rangka menguatkan brand equity di benak konsumen.

\section{Jenis dan Pendekatan Penelitian}

Jenis penelitian adalah kuantitatif yang yang identik dengan pendekatan deduktif, yaitu berangkat dari persoalan umum (teori) ke hal khusus sehingga penelitian ini harus ada landasan teorinya (Asnawi dan Masyhuri, 2011:20).

\section{Populasi dan Sampel}

Populasi (population) adalah serumpun atau sekelompok objek yang menjadi masalah sasaran penelitian. Populasi yang digunakan dalam penelitian ini adalah seluruh nasabah perbankan syariah di Kota Malang. Menurut Malhotra dalam Asnawi dan Masyhuri (2011:143), responden yang akan dijadikan sebagai sampel dalam penelitian dengan populasi yang tidak di ketahui jumlahnya, maka ditentukan paling sedikit 4 sampai 5 kali jumlah item pertanyaan. Penelitian ini menggunakan 18 pertanyaan. Sehingga jumlah sampel yang diambil adalah 90 sampel (18 pertanyaan kali 5) namun untuk lebih menguatkan maka digunakan 102 sampel.

\section{Teknik Pengambilan Sampel}

Dalam penelitian ini peneliti mengambil sampel dengan metode sampling aksidental atau accidental sampling (Supranto, 2001:51). Menurut Asnawi dan Masyhuri (2011:130) cara pengambilan sampel secara kebetulan (spontanitas) yaitu anggota yang secara kebetulan dijumpai oleh peneliti pada saat penelitian, maka itulah menjadi sampelnya.

\section{Data dan Jenis Data}

Menurut Asnawi dan Masyhuri, (2011:153) data adalah catatan keterangan sesuai bukti kebenaran; bahan-bahan yang dipakai sebagai dukungan penelitian. Sumber data dalam penelitian ada dua, yaitu data primer dan sekunder.

\section{Teknik Pengumpulan Data}

Untuk memperoleh data secara terperinci dan baik maka penliti menggunakan beberapa metode, yaitu daftar pertanyaan (questionnair), wawancara dan dokumentasi. 


\section{Definisi Operasional Variabel}

Variabel bebas (X) adalah integrated marketing communication terdiri dari lima variabel, yaitu:

- Periklanan (advertising)(X1): Segala biaya yang harus dikeluarkan sponsor untuk melakukan presentasi dan promosi nonpersonal dalam bentuk gagasan, barang, atau jasa. Contoh: Iklan media cetak, iklan media elektronik, brosur, buklet, poster, leaflet, billboard, dan lain-lain.

- Promosi penjualan (sales promotion)(X2): Berbagai insentif jangka pendek untuk mendorong pembelian atau penjualan suatu produk atau jasa. Contoh: Kupon, hadiah, diskon, produk sample, pameran dagang, games, dan lain-lain.

- Hubungan masyarakat dan publisitas (public relations \& publicity)(X3): Hubungan masyarakat adalah membangun hubungan baik dengan publik terkait untuk memperoleh dukungan, membangun "citra perusahaan" yang baik, dan menangani atau mengklarifikasi isu, cerita, dan peristiwa yang dapat merugikan. Sedangkan publisitas adalah stimulasi nonpersonal terhadap permintaan barang, jasa, ide, dan sebagainya dengan berita komersial yang berarti dalam media massa, dan tidak berbayar untuk mempromosikan dan untuk melindungi citra perusahaan atau produknya. Contoh: Seminar, press release, sponsorship, majalah perusahaan, events, lobbying, dan lain-lain.

- Penjualan personal (personal selling)(X4): Interaksi langsung dengan satu calon pembeli atau lebih untuk melakukan presentasi dalam rangka mensukseskan penjualan dan membangun hubungan dengan pelanggan. Contoh: Presentasi penjualan, pameran dagang, dan program insentif.

- Pemasaran langsung (direct marketing)(X5): Komunikasi langsung dengan sejumlah konsumen sasaran untuk memperoleh tanggapan langsung. Contoh: Katalog, surat, telemarketing, fax mail, internet, dan lain-lain.

Variabel terikat (Y) dalam penelitian ini adalah ekuitas merek (brand equity). Menurut Tjiptono (2005:40) indikator ekuitas merek terdiri dari Brand awareness (Kesadaran merek), Brand association (Asosiasi merek), Brand loyalitas (Loyalitas merek), dan Perceived quality (Persepsi kualitas).

\section{Teknik Analisis Data}

Untuk mengetahui pengaruh integrated marketing communication terhadap brand equity maka data dianalisis dengan menggunakan analisis regresi linier berganda dengan software SPSS.

\section{HASIL PENELITIAN \\ Karakteristik Responden}

Responden dalam penelitian ini adalah setiap nasabah bank syariah di Kota Malang yang berjumlah 102 orang. Sebagian besar usia responden adalah 15-25 
tahun dengan jumlah 78 responden (76.4\%), usia 26-35 tahun dengan jumlah 13 responden (12.7\%), usia 36-45 tahun dengan jumlah 8 responden (7.8\%), dan usia $>45$ Tahun dengan jumlah 3 responden (2.9\%). Responden berjenis kelamin pria berjumlah 37 responden (36.3\%), dan sebanyak 65 responden $(63.7 \%)$ berjenis kelamin wanita sehingga dapat disimpulkan bahwa responden berjenis kelamin wanita lebih banyak dari pada pria. Berdasarkan jenis pekerjaan, responden yang terbanyak adalah pelajar/ mahasiswa yang berjumlah 72 (70.6\%). Dengan rincian, Pegawai Swasta 14 responden 13.7\%), Wiraswasta 4 responden (3.9\%), Pelajar/ Mahasiswa 72 responden (70,6\%), PNS 11 responden (10.8\%) dan Lainnya (3\%).

Berdasarkan jenis bank syariah, responden merupakan nasabah beberapa bank syariah dengan rincian nasabah Bank Muamalat Indonesia sebanyak 23 orang (22.5\%), Bank Syariah Mandiri sebanyak 20 orang (19.6\%), BTN Syariah sebanyak 20 orang $(19.6 \%)$, BRI Syariah sebanyak 24 orang (23.5\%), BMT Al-Kamil sebanyak 8 orang $(7.8 \%)$, dan sisanya sebanyak 7 orang $(6,9 \%)$ adalah nasabah BNI Syariah. Sehingga dapat disimpulkan bahwa responden terbanyak adalah nasabah BRI Syariah sebanyak 24 orang atau 23.5\%. Berdasarkan jangka waktu atau lamanya responden menjadi nasabah bank syariah dengan rincian kurang dari dua tahun sebanyak 62 orang (60.8\%), antara dua sampai 5 tahun sebanyak 34 orang (33.3\%), dan lebih dari lima tahun sebanyak 6 orang (5.9\%). Sehingga dapat disimpulkan bahwa jangka waktu atau lamanya responden menjadi nasabah bank syariah yang terbanyak adalah kurang dari dua tahun yaitu sebanyak 62 orang. Hal ini selaras dengan usia responden yang terbanyak yaitu 15-25 tahun.

\section{Uji Validitas}

Uji validitas menggunakan korelasi product moment, bila korelasi $\mathrm{r}$ di atas 0,30 maka dapat disimpulkan bahwa butir instrumen tersebut valid sebaliknya bila korelasi $r$ dibawah 0,30 maka dapat disimpulkan bahwa butir instrumen tersebut tidak valid sehingga harus diperbaiki atau di buang. Berdasarkan hasil analisis, semua item pertanyaan mempunyai nilai probabilitas lebih kecil dari 0,05 dan nilai $r$ $\geq 0.30$. Dengan demikian berarti bahwa item pertanyan bisa dikatakan valid.

\section{Uji Reliabilitas}

Uji reliabilitas menunjukkan sesuatu instrumen cukup dapat dipercaya untuk digunakan sebagai alat pengumpul data karena instrumen tersebut sudah baik. Untuk mengetahui suatu alat ukur itu reliabel dapat diuji dengan menggunakan rumus Alpha Cronbach. Apabila variabel yang diteliti mempunyai cronbach's alpha $(\alpha)>60 \%(0,60)$ maka variabel tersebut dikatakan reliabel sebaliknya cronbach's alpha $(\alpha)<60 \%(0,60)$ maka variabel tersebut dikatakan tidak reliabel. Hasil uji reliabilitas menunjukkan bahwa semua variabel adalah reliabel. 


\section{Uji Asumsi Klasik}

\section{Uji Non-Multikolinieritas}

Tabel 1. Hasil Uji Asumsi Non-Multikolinieritas

\begin{tabular}{|c|c|c|c|c|c|c|c|c|}
\hline \multicolumn{9}{|c|}{ Coefficients $^{\mathrm{a}}$} \\
\hline \multirow{2}{*}{\multicolumn{2}{|c|}{ Model }} & \multicolumn{2}{|c|}{$\begin{array}{l}\text { Unstandardized } \\
\text { Coefficients }\end{array}$} & \multirow{2}{*}{$\begin{array}{c}\begin{array}{c}\text { Standardized } \\
\text { Coefficients }\end{array} \\
\text { Beta }\end{array}$} & \multirow{3}{*}{$\frac{\mathbf{t}}{6.262}$} & \multirow{3}{*}{$\begin{array}{l}\text { Sig. } \\
.000\end{array}$} & \multicolumn{2}{|c|}{$\begin{array}{l}\text { Collinearity } \\
\text { Statistics }\end{array}$} \\
\hline & & B & Std. Error & & & & Tolerance & VIF \\
\hline 1 & (Constant) & 8.606 & 1.374 & & & & & \\
\hline & $\mathrm{x} 1$ & .226 & .169 & .140 & 1.332 & .186 & .664 & 1.506 \\
\hline & $\mathrm{x} 2$ & -.085 & .096 & -.096 & -.890 & .376 & .628 & 1.591 \\
\hline & $\mathrm{x} 3$ & .457 & .131 & .439 & 3.493 & .001 & .467 & 2.141 \\
\hline & $\mathrm{x} 4$ & .006 & .126 & .006 & .048 & .962 & .504 & 1.983 \\
\hline & $\mathrm{x} 5$ & .137 & .104 & .132 & 1.318 & .191 & .733 & 1.364 \\
\hline
\end{tabular}

a. Dependent Variable: y

Sumber: Data Diolah

Dari hasil pengujian multikolinearitas pada tabel diatas dapat disimpulkan bahwa nilai VIF untuk X1 sampai X5 tidak melebihi nilai 5 dan nilai tolerance mendekati angka 1. Ini menunjukkan pada item tersebut tidak terdapat masalah multikolinieritas.

\section{Uji Normalitas}

Hasil pengujian menunjukkan nilai signifikansi sebesar 0,213>0,05, maka asumsi normalitas terpenuhi.

\section{Uji Non-Heteroskedastisitas}

Dari tabel diatas hasil pengujian heteroskedastisitas menunjukkan bahwa signifikansi hasil korelasi lebih besar dari 0,05 (5\%), sehingga dapat diketahui bahwa pada model regresi yang digunakan tidak terjadi heteroskedastisitas. 
Tabel 2. Hasil Uji Autokorelasi

\begin{tabular}{lrrrrr}
\multicolumn{6}{c}{ Model Summary } \\
\hline Model & R & R Square & \multicolumn{1}{c}{$\begin{array}{l}\text { Adjusted R } \\
\text { Square }\end{array}$} & $\begin{array}{l}\text { Std. Error of } \\
\text { the Estimate }\end{array}$ & \multicolumn{2}{c}{ Durbin-Watson } \\
\hline 1 & $.540^{\mathrm{a}}$ & .292 & .255 & 2.031 & 1.804 \\
\hline
\end{tabular}

a. Predictors: (Constant), Direct Marketing/Penjualan Langsung, Advertising/Periklanan, Personal Selling/Penjualan Pribadi, Sales Promotion/Promosi Penjualan, Public Relation/HUMAS

b. Dependent Variable: Brand Equity/Ekuitas Merk

Sumber: Data Diolah

\section{Uji Autokorelasi}

Dari output SPSS di atas diperoleh nilai DW sebesar 1.804 yang berarti $-2<1.804<2$, maka model regresi yang terbentuk tidak terjadi autokorelasi.

\section{Uji Linieritas}

Berdasarkan hasil analisis dapat diketahui jika nilai sig $\mathrm{f}$ di bawah 0,05 maka terjadi linieritas.

\section{Analisis Regresi Linier Berganda}

Persamaan regresi linier berganda merupakan persamaan regresi dengan menggunakan dua atau lebih variabel independen. Berdasarkan tabel 1 dapat dirumuskan bentuk persamaan regresi linier berganda sebagai berikut:

$\mathrm{Y}=8,606+0,226 \mathrm{X} 1-0,085 \mathrm{X} 2+0,457 \mathrm{X} 3+0,006 \mathrm{X} 4+0,137 \mathrm{X} 5$.

\section{Keterangan:}

\section{- $\mathrm{a}=8.606$}

Hal ini berarti jika variabel Advertising (X1), sales promotion (X2), public relation (X3), personal selling (X4), dan direct marketing (X5) konstan maka variabel Y sama dengan 8.606.

- $\quad \mathrm{b} 1=0.226$

Dengan asumsi variabel sales promotion (X2), public relation (X3), personal selling (X4), dan direct marketing (X5) konstan, jika variabel advertising (X1) naik sebesar 1\% maka variabel brand equity (Y) juga akan naik sebesar $0.226 \%$.

- $\quad \mathrm{b} 2=-0.085$

Dengan asumsi variabel advertising (X1), public relation (X3), personal selling (X4), dan direct marketing (X5) konstan, jika variabel sales promotion (X2) naik sebesar 1\% maka variabel brand equity (Y) akan turun sebesar $0.085 \%$.

- $\quad$ b3 $=0.457$

Dengan asumsi variabel advertising (X1), sales promotion (X2), personal selling (X4), dan direct marketing (X5) konstan, jika variabel public relation (X3) naik sebesar 1\% maka variabel brand equity (Y) juga akan naik sebesar $0.457 \%$.

- $\quad \mathrm{b} 4=0.006$ 
Dengan asumsi variabel advertising (X1), sales promotion (X2), public relation (X3), dan direct marketing (X5) konstan, jika variabel personal selling (X4) naik sebesar 1\% maka variabel brand equity (Y) juga akan naik sebesar $0.006 \%$.

- $\quad \mathrm{b} 5=0.137$

Dengan asumsi variabel advertising (X1), sales promotion (X2), public relation (X3), dan personal selling (X4) konstan, jika variabel direct marketing (X5) naik sebesar 1\% maka variabel brand equity (Y) juga akan naik sebesar $0.137 \%$.

Tabel 3. Hasil Analisis Regresi Linier Berganda

\begin{tabular}{llrrrrr}
\multicolumn{7}{c}{ ANOVA $^{\mathbf{b}}$} \\
\hline Model & & Sum of Squares & df & Mean Square & F & Sig. \\
\hline 1 & Regression & 163.339 & 5 & 32.668 & 7.917 & $.000^{\text {a }}$ \\
& Residual & 396.122 & 96 & 4.126 & & \\
\hline & Total & 559.461 & 101 & & & \\
\hline
\end{tabular}

a. Predictors: (Constant), Direct Marketing/Penjualan Langsung, Advertising/Periklanan, Personal Selling/Penjualan Pribadi, Sales Promotion/Promosi Penjualan, Public Relation/HUMAS

b. Dependent Variable: Brand Equity/Ekuitas Merk

\begin{tabular}{|c|c|c|c|c|c|c|c|c|c|}
\hline \multicolumn{10}{|c|}{ Coefficients $^{a}$} \\
\hline & \multirow{2}{*}{ Model } & \multicolumn{2}{|c|}{$\begin{array}{l}\text { Unstandardized } \\
\text { Coefficients }\end{array}$} & $\begin{array}{l}\text { Standardized } \\
\text { Coefficients }\end{array}$ & \multirow{2}{*}{$\mathbf{t}$} & \multirow{2}{*}{ Sig. } & \multicolumn{3}{|c|}{ Correlations } \\
\hline & & B & Std. Error & Beta & & & $\begin{array}{l}\text { Zero- } \\
\text { order }\end{array}$ & Partial & Part \\
\hline \multirow[t]{6}{*}{1} & (Constant) & 8.606 & 1.374 & & 6.262 & .000 & & & \\
\hline & $\begin{array}{l}\text { Advertising/ } \\
\text { Periklanan }\end{array}$ & .226 & .169 & .140 & 1.332 & .186 & .318 & .135 & .114 \\
\hline & $\begin{array}{l}\text { Sales Promotion/ } \\
\text { Promo si Penjualan }\end{array}$ & -.085 & .096 & -.096 & -.890 & .376 & .217 & -.090 & -.076 \\
\hline & $\begin{array}{l}\text { Public Relation/ } \\
\text { HUMAS }\end{array}$ & .457 & .131 & .439 & 3.493 & .001 & .517 & .336 & .300 \\
\hline & $\begin{array}{l}\text { Personal Selling/ } \\
\text { Penjualan Pribadi }\end{array}$ & .006 & .126 & .006 & .048 & .962 & .365 & .005 & .004 \\
\hline & $\begin{array}{l}\text { Direct Marketing/ } \\
\text { Penjualan } \\
\text { Langsung }\end{array}$ & .137 & .104 & .132 & 1.318 & .191 & .296 & .133 & .113 \\
\hline
\end{tabular}

a. Dependent Variable: Brand Equity / Ekuitas Merk

Sumber: Data Diolah

\section{Uji Hipotesis}

\section{Uji Simultan (Uji F)}

Dari tabel 3 di atas menunjukan bahwa hasil signifikansi sebesar $0.000<0,05$ dan hasil $\mathrm{F}_{\text {hitung }}$ 7,917 > dari $\mathrm{F}_{\text {tabel }} 2$ 2,29. Maka dari analisis diatas dapat disimpulkan bahwa secara bersama-sama variabel bebas yang terdiri dari advertising $(X 1)$, sales promotion $(X 2)$, public relation $(X 3)$, personal selling $(X 4)$, dan direct 
marketing (X5) berpengaruh signifikan terhadap variabel brand equity (Y). Dengan kata lain $\mathrm{Ha}$ : diterima artinya variabel $(\mathrm{X})$ integrated marketing communication berpengaruh secara simultan terhadap brand equity (Y) bank syariah di Kota Malang.

\section{Uji Parsial (Uji t)}

Dari hasil output tabel 1 di atas dapat dijelaskan sebagai berikut Advertising (X1), Uji t terhadap variabel advertising $\left(\mathrm{X}_{1}\right)$ didapatkan $\mathrm{t}_{\text {hitung }}$ sebesar 1,332 dengan signifikansi $\mathrm{t}$ sebesar 0,186 . Karena $\mathrm{t}_{\text {hitung }}<\mathrm{t}_{\text {tabel }}(1,332<1,980)$ atau signifikansi $\mathrm{t}$ lebih besar dari $0,05(0,186>0,05)$, maka secara parsial variabel advertising $\left(\mathrm{X}_{1}\right)$ tidak berpengaruh signifikan terhadap brand equity (Y) bank syariah di Kota Malang. Sales Promotion (X2), Uji t terhadap variabel sales promotion $\left(\mathrm{X}_{2}\right)$ didapatkan $\mathrm{t}_{\text {hitung }}$ sebesar -0,890 dengan signifikansi $\mathrm{t}$ sebesar 0,376. Karena $\mathrm{t}_{\text {hitung }}<$ $\mathrm{t}_{\text {tabel }}(-0,890<1,980)$ atau signifikansi t lebih besar dari $0,05(0,376>0,05)$, maka secara parsial variabel sales promotion $\left(\mathrm{X}_{2}\right)$ tidak berpengaruh signifikan terhadap brand equity (Y) bank syariah di Kota Malang. Public Relation (X3), Uji t terhadap variabel public relation $\left(\mathrm{X}_{3}\right)$ didapatkan $\mathrm{t}_{\text {hitung }}$ sebesar 3,493 dengan signifikansi $\mathrm{t}$ sebesar 0,001 . Karena $\mathrm{t}_{\text {hitung }}>\mathrm{t}_{\text {tabel }}(3,493>1,980)$ atau signifikansi $\mathrm{t}$ lebih besar dari $0,05(0,001<0,05)$, maka secara parsial variabel public relation $\left(\mathrm{X}_{3}\right)$ berpengaruh signifikan terhadap brand equity (Y) bank syariah di Kota Malang. Personal Selling (X4), Uji t terhadap variabel personal selling $\left(\mathrm{X}_{4}\right)$ didapatkan $\mathrm{t}_{\text {hitung }}$ sebesar 0,048 dengan signifikansi $t$ sebesar 0,962. Karena $\mathrm{t}_{\text {hitung }}<\mathrm{t}_{\text {tabel }}(0,048<1,980)$ atau signifikansi t lebih besar dari 0,05 (0,962>0,05), maka secara parsial variabel personal selling $\left(\mathrm{X}_{4}\right)$ tidak berpengaruh signifikan terhadap brand equity $(\mathrm{Y})$ bank syariah di Kota Malang. Direct Marketing (X5), Uji t terhadap variabel direct marketing $\left(\mathrm{X}_{5}\right)$ didapatkan $\mathrm{t}_{\text {hitung }}$ sebesar 1,318 dengan signifikansi t sebesar 0,191. Karena $\mathrm{t}_{\text {hitung }}<\mathrm{t}_{\text {tabel }}(1,318<1,980)$ atau signifikansi t lebih besar dari 0,05 $(0,191>0,05)$, maka secara parsial variabel direct marketing $\left(\mathrm{X}_{5}\right)$ tidak berpengaruh signifikan terhadap brand equity (Y) bank syariah di Kota Malang.

\section{Uji Dominan}

Variabel integrated marketing communication yang berpengaruh terhadap brand equity bank syariah hanya public relation (X3). Sehingga hipotesis ketiga yang menyatakan bahwa variabel advertising berpengaruh dominan terhadap brand equity bank syariah di Kota Malang ditolak.

\section{Koefisien Determinasi}

Koefisien determinasi ditunjukkan oleh nilai adjusted $R$ square yang menunjukkan besarnya kontribusi variabel independen terhadap variabel dependen. Berdasarkan tabel 2 diketahui bahwa nilai adjusted $R$ square adalah sebesar 22,5\%. Hal ini 
berarti bahwa variabel independen yang terdiri dari advertising $(X 1)$, sales promotion (X2), public relation (X3), personal selling (X4), dan direct marketing (X5) mempunyai kontribusi atau mampu menjelaskan variabel brand equity (Y) sebesar $22,5 \%$ dan sisanya sebesar $77,5 \%$ dijelaskan oleh variabel lain.

\section{PEMBAHASAN}

Hasil penelitian menunjukkan bahwa secara simultan variabel independen yang terdiri dari advertising (X1), sales promotion (X2), public relation (X3), personal selling (X4), dan direct marketing (X5) berpengaruh signifikan terhadap variabel brand equity (Y). Hasil penelitian ini mendukung hasil penelitian Fathir Fathoni, Achmad Fauzi dan Kadarisman Hidayat (2011) yang menunjukkan bahwa variabel dari komunikasi pemasaran terpadu yaitu iklan, promosi penjualan, penjualan personal, hubungan masyarakat, pemasaran langsung, pemasaran interaktif dan corporate design secara bersama sama berpengaruh terhadap ekuitas merek.

Sedangkan secara parsial diketahui hanya variabel public relation (X3) yang berpengaruh signifikan terhadap brand equity (Y). Hal ini juga sesuai dengan hasil penelitian Fathir Fathoni, Achmad Fauzi dan Kadarisman Hidayat (2011) bahwa tidak semua variabel bebas berpengaruh signifikan terhadap ekuitas merek tetapi hanya variabel promosi penjualan, penjualan personal, pemasaran interaktif, dan corporate design yang berpengaruh signifikan terhadap ekuitas merek. Hal ini juga diperkuat dari nilai koefisien determinasi yang hanya sebesar 22,5\%. Sehingga variabel bebas hanya mampu menjelaskan variabel terikat sebesar 22,5\% dan sisanya dijelaskan oleh variabel lain yang tidak termasuk dalam penelitian ini.

Dilihat dari karakteristik responden bahwa mayoritas responden bukanlah orang yang lama menjadi nasabah bank syariah karena baru dua tahun menjadi nasabah bank syariah. Selain itu mayoritas responden adalah orang yang berusia muda yang tidak terlalu memberikan perhatian pada aktifitas bank syariah. Sehingga pengetahuan respoden tentang program-program atau kegiatan yang dilakukan oleh bank syariah masih tergolong kurang. Meskipun telah banyak program dan kegiatan komunikasi pemasaran yang telah dilakukan oleh perbankan syariah di Kota Malang ternyata masyarakat lebih mengenal program public relation saja. Oleh karena itu pihak perbankan syariah perlu untuk melakukan program komunikasi pemasaran terpadu secara lebih intens karena IMC tidak hanya public relation tetapi ada kegiatan lain seperti periklanan, promosi penjualan, penjualan secara pribadi, dan pemasaran langsung.

\section{Kesimpulan}

Variabel integrated marketing communication berpengaruh secara simultan terhadap brand equity bank syariah di Kota Malang. Secara parsial hanya variabel public relation yang berpengaruh terhadap brand equity bank syariah di Kota 
Malang sedangkan empat variabel yang lain tidak berpengaruh. Tidak ada variabel yang dominan karena yang berpengaruh secara parsial hanya satu variabel yaitu public relation.

\section{Saran}

Berdasarkan kesimpulan penelitian maka disarankan kepada pihak perbankan syariah di Kota Malang dalam rangka meningkatkan ekuitas merek, untuk memperhatikan kegiatan public relation karena dianggap dominan berpengaruh terhadap ekuitas merek perusahaan. Sedangkan bagi peneliti selanjutnya, disarankan untuk menambah variabel penelitian atau memfokuskan pada masing-masing variabel integrated marketing communication.

\section{DAFTAR PUSTAKA}

Asnawi, N., dan Masyhuri. 2011. Metodologi Riset Manajemen Pemasaran. Malang: UIN Maliki Press.

Brunello, A. 2013. The Relationship Between Integrated Marketing Communication and Brand Equity. International Journal of Communication Research. Vol. 3. Issue 1 January/March 2013. P. 9-14.

Danibrata, A. 2011. Pengaruh Integrated Marketing Communication terhadap Brand Equity pada Sebuah Bank Pemerintah di Jakarta. Jurnal Bisnis dan Akuntansi. Vol. 13. No. 1. April 2011. Hal. 21-38.

Kartajaya, H. 2010. The Official MIM Academy Coursebook Brand Operation. Jakarta: Erlangga.

Kotler, P., dan Gary, A. 2001. Prinsip-prinsip Pemasaran. Edisi Kedelapan Jilid 2. Jakarta: Erlangga.

Kotler, P., dan Keller, L. 2006. Manajemen Pemasaran. Edisi Dua Belas, Jilid 1. Jakarta: PT Indeks.

Madhavaram, B., Vishaq, B., and Robert, E., Mc. Donald. 2005. Integrated Marketing Communications and Brand Identity as Critical Component of Brand Equity: A Conceptual Framework and Research Propositions. Journal of Advertising.Vol 34, Issue 4.

Mihart, C. 2012. Impact of Integrated Marketing Communication on Consumer Behaviour: Effect on Consumer Decision-Making Process. International Journal of Marketing Studies. Vol. 4. No. 2. April 2012. P. 121-129.

Nasiha, S. 2010. Strategi Komunikasi Pemasaran Terpadu (Integrated Marketing Communication) dalam Mengokohkan Brand Dagadu Djokdja. Skripsi. Yogyakarta: UIN Sunan Kalijaga.

Setiadi, Nugroho, J. 2003. Perilaku Konsumen: Konsep dan Implikasi untuk Strategi dan Penelitian Pemasaran. Jakarta: Kencana Prenada Media Group.

Shimp, Terence, A. 2003. Periklanan dan Promosi (Aspek Tambahan Komunikasi Pemasaran Terpadu). Edisi Terjemahan. Jakarta: Erlangga.

Sulhan, M. 2011. Panduan Praktis analisis SPSS untuk Manajemen (Keuangan, SDM, Pemasaran). Center Laboratory and ICT CLICT Management. Malang. 
Simamora, H. 2007. Manajemen Pemasaran Internasional. Edisi dua, Jilid 2. Jakarta: PT Rineka Cipta.

Supranto. 2001. Teknik Riset Pemasaran dan Ramalan Penjualan. Edisi Revisi. Jakarta: PT Rineka Cipta.

Susanto, dan Wijarnako. 2004. Power Branding. Jakarta: Quantum Bisnis \& Manajemen.

Tempo Interaktif. 2010. Pertumbuhan Aset Perbankan Syariah Malang Menggembirakan. TEMPO.CO bisnis.

Tjiptono, F. 2005. Brand Management \& Strategy. Yogyakarta: Penerbit Andi.

Widyakusuma, E. 2012. Strategi Komunikasi Pemasaran PT Nokia Indomesia dalam Membangun Brand Awareness Konsumen pada Smartphone Nokia Seri Lumia. http://journal.unair.ac.id 